\title{
NILAI DAN PENGETAHUAN SEBAGAI PREDIKTOR INTENSI BELI MAKANAN ORGANIK
}

\author{
Tony Wijaya \\ Pascasarjana Fakultas Eekonomi Universitas Islam Indonesia Yogyakarta \\ Ringroad Utara, Depok, Sleman, Yogyakarta 55283 \\ Email: tonypascamm@yahoo.com
}

\begin{abstract}
Abstrak
Tujuan dari penelitian ini adalah untuk menguji pengaruh orientasi alami manusia, pengetahuan organik dan sikap pada makanan organik terhadap intensi beli makanan organik. Data didapatkan dengan kuesioner. Data survei terdiri dari 516 wanita yang telah menikah sebagai konsumen akhir makanan organik dari Yogyakarta, Jakarta dan Surabaya-Indonesia. Hasil uji empiris menunjukkan bahwa orientasi alami manusia dan pengetahuan organik berpengaruh signifikan terhadap sikap pada makanan organik. Sikap pada makanan organik berpengaruh signifikan terhadap intensi beli. Semua hipotesis dalam penelitian ini terbukti.
\end{abstract}

Kata Kunci: Makanan Organik, Orientasi Alami Manusia, Pengetahuan Organik, Intensi Beli

\begin{abstract}
This research aimed to examine a model which presents effects of man-nature orientation, of organic knowledge and attitude toward organic food to purchase intention of organic food. Data collection method of this research used questionnaire. Survey data was consisted of 516 married women as an end user of organic food from Yogyakarta, Jakarta and Surabaya-Indonesia. The empirical tests indicated that man-nature orientation and organic knowledge had significant effect on attitude toward organic food. Attitude toward organic food had significant effect on purchase intention of organic food. All hypotheses in this research were fully supported.
\end{abstract}

Keywords: Organic Food, Man-nature Orientation, Organic Knowledge, Purchase Intention

\section{PENDAHULUAN}

Perkembangan makanan organik di negara berkembang cukup baik terutama di negara-negara Eropa. Sektor pertanian organik di Uni Eropa diperkirakan dapat meningkat hingga 30\% pada 2010 dari seluruh area pertanian yang mana pada tahun 2005 sektor pertanian organik telah mencapai $10 \%$ dari seluruh area pertanian. Inggris sebagai salah satu pemimpin pasar dari makanan organik di Eropa memiliki perkiraan nilai pasar sebesar 1,2 miliar Poundsterling pada tahun 2003 atau sekitar setengah dari pemimpin pasar lain seperti Jerman (Padel \& Foster, 2005).

Pembelian makanan organik di Indonesia masih tergolong rendah. Hasil survei penelitian YLKI (2012) dengan 609 responden di beberapa wilayah Jakarta menunjukkan konsumen yang mengkonsumsi beras organik sebesar $24 \%$, mengkonsumsi buahbuahan sebesar $17 \%$ dan dalam bentuk bumbu-bumbu sebesar 3\%. Konsumen tidak membeli makanan organik dengan alasan di antaranya harga yang mahal, keterjangkauan dan akses tempat yang masih sangat sulit. Sementara 34\% lainnya (205 orang) tidak mengetahui tentang pangan organik. Dari penelaahan penelitian konsumsi organik oleh YLKI menunjukkan masih rendahnya konsumsi pangan organik di Indonesia. Masalah akses dan keterjangkauan masih menjadi persoalan utama konsumen jika ingin mendapatkan produk pangan organik. Minimnya informasi, terkait tempat penjualan dengan harga yang terjangkau merupakan salah satu masalah yang harus dicarikan jalan keluarnya. Selama ini sebagian besar konsumen membeli produk pangan organik di ritel modern. Sedikitnya konsumen yang mencari produk di pasar tradisional, mungkin terkait dengan minimnya tempat tersebut yang menyediakan produk pangan organik.

Pemahaman faktor-faktor yang berperan menjelaskan perilaku membeli makanan organik diharapkan mampu mengurangi degradasi lingkungan melalui aspek konsumsi yang ramah lingkungan. Perilaku beli makanan organik dapat dijadikan sebagai sasaran dalam mengarahkan konsumsi yang ramah lingkungan serta perbaikan mutu hidup. Pentingnya pemahaman perilaku beli makanan organik dari sisi 
konsumen antara lain alasan kesehatan, kualitas hidup maupun alasan mengurangi degradasi lingkungan (Tsakiridou et al., 2008). Dari sisi pemasar, pemahaman perilaku beli makanan organik penting sebagai bagian dari komunikasi dan strategi pemasaran bagi segemen yang potensial (Kalafatis et al., 1999).

Beberapa studi perilaku konsumen berupaya mengidentifikasi faktor-faktor yang berperan bagi perilaku konsumen makanan organik. Studi-studi tersebut mencoba mengeksplorasi variabel-variabel yang menjadi anteseden bagi perilaku pembelian makanan organik. Beberapa temuan dalam penelitian perilaku konsumen makanan organik menegaskan ada variabel anteseden yang berperan menjelaskan perilaku pembelian makanan organik yaitu nilai konsumen (Chan, 2001; Chan \& Lau, 2000; Fraj \& Martinez, 2006; Junaedi, 2007; Sihombing, 2007), pengetahuan (Chan, 1999; Chan \& Lau, 2000; Laroche et al., 2001; Magistris \& Gracia, 2008), sikap konsumen (Aertsens et al., 2009; Chiou, 1998; Dispoto, 1997; Gracia \& Magistris, 2007; Kalafatis et al., 1999; Ling-Yee, 1997; Lodorfos \& Dennis, 2008; Maloney \& Ward, 1973; Tarkiainen \& Sundqvist, 2005; Suprapto \& Wijaya, 2012).

Masalah lingkungan hidup berakar dari aktivitas manusia serta pola konsumsi dan produksi manusia sehingga diperlukan kepedulian manusia khususnya masyarakat dalam menjaga kualitas lingkungan. Perilaku menjaga kualitas lingkungan hidup sangat bergantung pada tingkat pengetahuan, sikap, dan nilai yang ada pada konsumen sebagai umat manusia (Mansaray \& Abijoye, 1998; Chen \& Chai, 2010; Said, 2003).

Nilai dan pengetahuan merupakan faktor esensial yang perlu dipertimbangkan dalam penelitian perilaku konsumen pangan organik. Kalafatis et al. (1999) dalam penelitiannya yang menggunakan model dasar teori perilaku terencana menyarankan perlunya melibatkan sejumlah orientasi budaya berupa nilainilai personal lainnya dalam memprediksi intensi beli makanan organik. Chiou (1998) dalam penelitiannya mengenai intensi beli makanan organik juga merekomendasikan perlunya mempertimbangkan tekanan sosial dan orientasi budaya atau nilai yang berbeda dalam memprediksi intensi beli makanan organik. Aertsens et al. (2009) dalam menelaah sejumlah determinan aspek dasar yang mendasari perilaku konsumsi makanan organik menyarankan pentingnya mempertimbangkan aspek nilai sebagai determinan dalam memprediksi perilaku beli makanan organik.

Konsep tentang makanan dan nutrisi memiliki nilai sosial, karena pilihan personal dipengaruhi oleh nilai-nilai personal dan nilai-nilai yang diakui lingkungan sosial (Fotopoulos \& Krystallis, 2002). Nilainilai merupakan variabel psikografis yang menjadi orientasi perusahaan dalam mengidentifikasi segmentasi konsumen untuk produk-produk ramah lingkungan (Engel et al., 2000; Fraj \& Martinez, 2006). Nilai sering digunakan oleh pemasar dalam mengidentifikasi perilaku konsumen ramah lingkungan. Nilai-nilai dipertimbangkan sebagai suatu variabel penting dalam memahami perilaku konsumen, karena nilai menghadirkan tujuan fundamental yang dicari oleh konsumen, yang berguna untuk pemuasan bagi segmen mereka (Divine \& Lepisto, 2005).

Selain aspek nilai, aspek pengetahuan konsumen pada produk juga perlu dipertimbangkan dalam penelitian perilaku konsumen karena berkaitan dengan pertimbangan pembelian. Lodorfos \& Dennis (2008) menyarankan pentingnya informasi sebagai bagian dari pengambilan keputusan konsumen organik. Aspek pengetahuan merupakan aspek yang mempengaruhi perilaku pembelian (Engel et al., 2005; Kotler, 2006), perilaku pencarian informasi (Brucks, 1985) dan membantu konsumen mempelajari produk baru (Moreau et al., 2001). Sikap yang menjadi komponen dasar dalam teori perilaku terencana ditentukan oleh tingkat keyakinan individu dan dapat berubah sesuai dengan tingkat pengetahuan (Aertsens et al., 2009). Aspek pengetahuan produk menjadi salah satu pertimbangan konsumen dalam mengevaluasi produk. Pengetahuan produk menunjukkan seberapa besar informasi produk yang telah diserap oleh konsumen (Engel et al, 2005).

Penelitian yang dilakukan akan mempertimbangkan nilai konsumen yang berorientasi alami manusia dan pengetahuan organik, dalam memprediksi intensi beli makanan organik. Sebagai suatu feno-mena dalam perilaku konsumen, produk makanan masih membutuhkan kajian lebih mendalam untuk memperoleh kepercayaan dan legitimasi konsumen (Bhaskaran \& Hardley, 2002). Dengan demikian makanan organik penting untuk dipahami oleh pemasar sebagai dasar dalam mengembangkan komunikasi yang efektif. Tujuan dari penelitian ini adalah menguji pengaruh simultan dan parsial dari variabel prediktor yang diteliti terhadap intensi beli makanan organik sesuai dengan rancangan model yaitu pengaruh variabel nilai orientasi alami manusia dan pengetahuan organik terhadap intensi beli melalui sikap pada makanan organik.

\section{LANDASAN TEORI DAN HIPOTESIS}

\section{Nilai Orientasi Alami Manusia dan Sikap pada Makanan Organik}

Nilai merupakan faktor penting yang mendorong individu dalam melihat dunia (Engel et al., 2005; Homer \& Khale, 1988). Studi literatur yang 
membandingkan antar negara atau antar kota mengungkapkan bahwa nilai-nilai suatu masyarakat tertentu berpengaruh pada perilaku pembelian yang memperhatikan dampak lingkungan sosial dan individu (Chan \& Lau, 2000; Fotopoulos \& Krystallis, 2002). Nilai yang dianut seseorang akan menentukan konsumsinya, karena nilai-nilai merupakan manifestasi kognitif atas tuntutan-tuntutan universal manusiawi seperti biologis, interaksi sosial, dan tuntutan pranata sosial terhadap individu (Schwartz \& Bilsky, 1987). Sikap individu pada umumnya didasarkan pada nilai yang dianutnya untuk membuat keputusan relevan.

Nilai merupakan pertimbangan yang fundamental bagi hubungan konsumen dengan lingkungan. Individu yang menganut nilai akan memberikan pengaruh terhadap perilaku konsumsi. Pengaruh tersebut membentuk sebuah kesadaran akan manfaat yang diperoleh setelah mengkonsumsi barang tersebut. Nilai yang dianut setiap individu akan mempengaruhi sikap, dari sikap tersebut akan mempengaruhi perilaku konsumsinya (Mowen \& Minor, 2006).

Makanan organik sebagai produk ramah lingkungan merupakan elemen sistem keyakinan individu (Dembkowski \& Lloyd, 1994). Secara tradisional keyakinan manfaat makanan dan nutrisi merupakan bagian budaya bagi bangsa Cina, Jepang, Korea dan beberapa negara Asia lainnya (Verschuren, 2002; Westrate et al., 2002). Nilai adalah kepercayaan atau segala sesuatu yang dianggap penting oleh seseorang atau masyarakat. Nilai bisa berarti sebuah kepercayaan tentang suatu hal, namun nilai bukan hanya kepercayaan. Dalam berperilaku seseorang diarahkan oleh nilai yang sesuai dengan budayanya.

Konsumen yang memperhatikan produk ramah lingkungan diharapkan memiliki nilai-nilai orientasi pada hubungan manusia dengan alam sehingga memahami dampak konsumsi produk pada lingkungan. Orientasi nilai konsumen dapat dibedakan dalam beberapa tipe yaitu mannature orientation, manhimself orientation, relational orientation, past-time orientation dan activity orientation. Tipe nilai yang dikemukakan oleh Kluckhohn \& Strodtbeck (1961) dalam Variations in Value Orientations, lebih banyak digunakan dalam penelitian perilaku konsumen dibandingkan tipe nilai lainnya (Churchill, 1979; Engel et al., 2005). Kategorisasi yang dilakukan oleh Chan \& Lau (2000), Chan, (2001) dan Sihombing (2007) menunjukkan bahwa tipe nilai menurut Kluckhohn dan Strodtbeck (1961) yang mampu memprediksi perilaku pembelian produk hijau atau ramah lingkungan adalah man-nature orientation atau orientasi alami manusia.

Orientasi alami manusia (mannature orientation) berfokus pada hubungan manusia dengan alam dan pada dasarnya manusia mengarah pada kehidupan yang harmonis dengan lingkungannya. Orientasi alami manusia memiliki dimensi subjugation to nature, harmony with nature dan mastery over nature (Chan \& Lau, 2000). Penduduk Asia memandang diri mereka sebagai bagian dari alam dan hidup harmonis dengan alam atau berorientasi pada alam (De Mooij, 2004) yang disebut Chan (2001) sebagai orientasi alami manusia (man-nature orientation). Konsumen yang memiliki orientasi alami manusia cenderung mempertimbangkan akibat-akibat konsumsi pada lingkungan sehingga memiliki sikap ramah lingkungan (Chan, 2001).

Beberapa studi menunjukkan terdapat inkonsistensi hasil penelitian hubungan antara nilai konsumen dengan sikap konsumen terhadap makanan organik. Nilai konsumen memiliki pengaruh yang positif terhadap sikap konsumen pada produk organik (Dreezens et al., 2005; Krystallis et al., 2008; Grunert \& Juhl, 1995; Loureiro et al., 2001; Magnusson et al., 2001; Durham \& Andrade, 2005; Kuhar \& Juvancic, 2005; Midmore et al., 2005; Padel \& Foster, 2005; Verhoef, 2005; Gracia \& De Magistris, 2007; Stobbelaar et al., 2007; Junaedi, 2007). Berbeda dengan hasil penelitian lainnya yang mengemukakan bahwa nilai konsumen tidak berpengaruh signifikan terhadap sikap konsumen pada makanan organik (Chryssohoidis \& Krystallis, 2005; Baker et al., 2004).

Orientasi alami manusia berisi nilai-nilai yang mengarah pada hubungan manusia dengan alam sehingga konsumen berupaya mencari atau memperoleh informasi-informasi yang berkaitan dengan masalah lingkungan. Orientasi alami manusia berpengaruh positif terhadap sikap konsumen (Chan \& Lau, 2000; Chan, 2001). Dengan demikian konsumen yang memiliki orientasi nilai alami manusia akan memiliki sikap yang mendukung konsumsi produk organik (Wijaya \& Hidayat, 2011). Studi meta-analisis menunjukkan ada hubungan nilai konsumen dengan sikap terhadap produk organik yaitu sebesar 0,324. Hipotesis yang diajukan sebagai berikut:

$\boldsymbol{H}_{I}$ : Nilai orientasi alami manusia berpengaruh positif terhadap sikap pada makanan organik.

\section{Pengetahuan Organik dan Sikap pada Makanan Organik}

Pengetahuan konsumen adalah semua informasi yang dimiliki konsumen mengenai berbagai macam produk, serta pengetahuan lainnya yang terkait dan informasi yang berhubungan dengan perannya sebagai konsumen (Engel et al, 2005). Pengetahuan dalam riset konsumen adalah salah satu karakteristik yang mempengaruhi proses pengambilan keputusan. 
Pengetahuan merupakan faktor relevan yang mempengaruhi konsumen dalam mengumpulkan dan mengorganisasikan informasi yang diterima (Alba \& Hutchinson, 1987), menggunakan informasi yang diterima untuk pembuatan keputusan dan menggunakan informasi sebagai evaluasi produk yang akan dikonsumsi (Martin \& Simintras, 1995).

Konsumen mempertimbangkan akibat umum dari konsumsi pribadi dengan mengevaluasi manfaat dan dampak dari konsumsi berdasarkan pengetahuan yang dimilikinya. Pengetahuan merupakan konstruk yang penting dalam memahami perilaku konsumen, karena perannya dalam menentukan perilaku pencarian informasi (Brucks, 1985), mempelajari produk baru (Wood \& Lynch, 2002), proses adopsi (Moreau et al., 2001) dan penggunaan label makanan (Nayga, 2000). Pengetahuan organik didefinisikan sebagai kemampuan konsumen mengidentifikasi sejumlah konsep yang berkaitan dengan produk organik melalui informasi yang dimiliki konsumen (Magistris \& Gracia, 2008; Chan \& Lau, 2000).

Peattie (1998) mengemukakan secara analogi teori pemasaran produk hijau, bahwa konsumen yang memiliki pengetahuan lingkungan yang tinggi cenderung memiliki motivasi untuk melakukan pembelian produk hijau. Konsumen yang menyadari pentingnya konsekuensi konsumsi akan mendorong pembelian makanan organik (Follows \& Jobber, 2000; Vlosky et al., 1999; Bui, 2005; Laroche et al., 2001). Hubungan pengetahuan organik dengan sikap konsumen berdasarkan hasil-hasil penelitian terdahulu masih menunjukkan adanya kontroversi pendapat. Beberapa studi menunjukkan terdapat inkonsistensi hasil penelitian hubungan pengetahuan dengan sikap konsumen terhadap makanan organik.

Pengetahuan organik berperan menstimulasi sikap konsumen terhadap produk organik secara positif (Amyx et al., 1994; Vining \& Ebreo, 1990; Chan, 1999; Yiridoe et al., 2005; Poelman et al., 2008; Schlegelmilch et al., 1996; Junaedi, 2007; Gracia \& Magistris, 2007; Magistris \& Gracia, 2008). Chan (2001) menjelaskan bahwa pengetahuan berpengaruh terhadap sikap konsumen pada makanan organik, namun dengan tingkat signifikansi $10 \%$. Beberapa hasil penelitian menunjukkan hasil yang berbeda. Pengetahuan organik tidak berpengaruh terhadap sikap konsumen pada makanan organik (Maloney \& Ward, 1973; Ramsey \& Rickson, 1976; Laroche et al., 2001; Chiou, 1998; Arbuthnot \& Lingg, 1975; Geller, 1981; Schahn \& Holzher, 1990). Vlosky et al. (1999) dalam penelitiannya melaporkan bahwa konsumen yang memiliki pengetahuan yang tinggi terhadap produk organik cenderung rela membayar lebih untuk produk organik, karena didukung oleh sikap yang positif pada produk organik. Pengetahuan organik berkaitan dengan keyakinan konsumen ter-hadap makanan organik.

Pengetahuan merupakan sumber informasi yang berperan bagi individu dalam mempertimbangkan keputusan konsumsi makanan organik, sehingga pengetahuan organik berpengaruh terhadap evaluasi konsumen terhadap makanan organik (Amyx et al., 1994; Vining \& Ebreo, 1990; Chan, 1999; Yiridoe et al., 2005; Poelman et al., 2008; Schlegelmilch et al., 1996; Junaedi, 2007; Gracia \& Magistris, 2007; Magistris \& Gracia, 2008). Konsumen yang memiliki pengetahuan organik cenderung memiliki sikap positif terhadap makanan organik karena yakin makanan organik bermanfaat bagi konsumen. Konsumen juga yakin dengan mengkonsumsi makanan organik, konsumen akan memperoleh manfaat seperti kesehatan, kealamian dan keamanan konsumsi. Pengetahuan organik merupakan faktor penting karena mewakili kemampuan konsumen dalam membedakan produk organik atau non organik serta membentuk sikap positif pada produk organik (Magistris \& Gracia, 2008).

Secara umum studi meta-analisis menunjukkan ada hubungan pengetahuan organik dengan sikap terhadap produk organik yaitu sebesar 0,30 (Chan, 2001). Semakin tinggi skor pengetahuan organik maka semakin positif sikap konsumen pada makanan organik. Hipotesis yang diajukan dalam penelitian ini yaitu:

$\boldsymbol{H}_{2}$ : Pengetahuan organik berpengaruh positif terhadap sikap pada makanan organik.

\section{Sikap pada Makanan Organik dan Intensi Beli Makanan Organik}

Beberapa temuan dalam penelitian perilaku konsumen mendukung adanya pengaruh sikap terhadap perilaku terhadap intensi beli makanan organik (Chan, 1999; Chan \& Lau, 2000; Dispoto, 1997; Ling -Yee, 1997; Maloney \& Ward, 1973; Wijaya, 2013; Gracia \& Magistris, 2007; Kalafatis et al., 1999; Chiou, 1998; Aertsens et al., 2009; Tarkiainen \& Sundqvist, 2005; Sampson, 2009).

Para peneliti melakukan penelitian sikap untuk memperoleh kepastian apakah sikap dapat menjadi prediktor yang akurat terhadap perilaku. Aplikasi Theory of Reasoned Action dalam psikologi sosial dan industri sudah membuktikan bahwa sikap terhadap perilaku memang telah menjadi prediktor yang akurat bagi perilaku meskipun prediksi itu dilakukan melalui variabel intensi (intention). Terbentuknya intensi dapat diterangkan dengan teori perilaku terencana yang mengasumsikan manusia selalu mem- 
punyai tujuan dalam berperilaku (Fishbein \& Ajzen, 1975). Sikap berperilaku, yang merupakan dasar bagi pembentukan intensi. Terdapat dua aspek pokok dalam sikap terhadap perilaku, yaitu: keyakinan individu bahwa menampilkan atau tidak menampilkan perilaku tertentu akan menghasilkan akibat-akibat atau hasil-hasil tertentu dan merupakan aspek pengetahuan individu tentang obyek sikap dapat pula berupa opini individu hal yang belum tentu sesuai dengan kenyataan.

Semakin positif keyakinan individu akan akibat dari suatu obyek sikap, maka akan semakin positif pula sikap individu terhadap obyek sikap tersebut, demikian pula sebaliknya (Fishbein \& Ajzen, 1975). Evaluasi berakibat pada perilaku penilaian yang diberikan individu terhadap tiap-tiap akibat atau hasil yang diperoleh oleh individu. Evaluasi atau penilaian individu dapat bersifat menguntungkan atau merugikan saat menampilkan atau tidak menampilkan perilaku tertentu. Semakin tinggi skor sikap terhadap makanan organik maka semakin tinggi intensi beli makanan organik.

Hasil penelitian menunjukkan adanya hubungan positif antara sikap pada makanan organik dan intensi beli makanan organik (Chan, 1999; Chan \& Lau, 2000; Dispoto, 1997; Ling-Yee, 1997; Maloney \& Ward, 1973; Wijaya, 2013; Wijaya \& Hidayat, 2011; Gracia \& Magistris, 2007; Kalafatis et al., 1999; Chiou, 1998; Aertsens et al., 2009). Studi metaanalisis menunjukkan adanya hubungan sikap pada makanan organik dengan intensi beli sebesar 0,497. Peneliti dalam studi pendahuluan menemukan secara operasional, evaluasi dan keyakinan konsumen dalam membeli makanan organik berdasarkan pada kesehatan, keamanan, kealamian, kesegaran dan respon negatif yaitu tidak tahan lama atau gangguan serangga (Wijaya, 2013). Hipotesis yang diajukan dalam penelitian ini yaitu:

$\boldsymbol{H}_{3}$ : Sikap pada makanan organik berpengaruh positif terhadap intensi beli makanan organik.

\section{METODE PENELITIAN}

Paradigma dalam penelitian ini berorientasi pada paradigma positivisme, sebuah paradigma yang dominan diterapkan dalam penelitian perilaku konsumen sampai saat ini. Paradigma positivisme menekankan verifikasi teori atau pengujian model, yang cenderung bersifat deduktif dengan mengukur fenomena dengan ketepatan variabel dan melakukan pengujian hipotesis. Metode pengumpulan data dilakukan dengan survei menggunakan kuesioner. Desain survei ini dipilih dengan melibatkan konsumen yang berdomisili di tiga kota besar di pulau Jawa yang meliputi Jakarta, Yogyakarta dan Surabaya sebagai sampel penelitian untuk menarik suatu generalisasi atau kesimpulan yang bersifat umum, menolak atau membenarkan suatu hasil penelitian terdahulu dengan konteks tertentu. Responden yang berhasil dikumpulkan sebanyak 516 responden.

\section{Konstruk Variabel dan Definisi Operasional Variabel}

Tataran data variabel penelitian yang dikumpulkan berbentuk skor data rentang (interval) atau menggunakan skala interval yaitu rentang 1-5. Definisi operasional yang berkaitan dengan arti dari seluruh variabel laten yang digunakan dalam penelitian lapangan ini dijabarkan serta dijelaskan sebagai berikut ini:

1. Variabel Intensi Beli Makanan Organik (IB)

Intensi beli makanan organik yaitu keinginan atau ekspresi niat individu untuk berkomitmen pada aktivitas-aktivitas mengkonsumsi makanan organik (Chan \& Lau, 2000). Intensi beli makanan organik diukur dengan indikator a) mempertimbangkan membeli makanan yang berlabel organik untuk konsumsi keluarga, b) berniat membeli makanan yang diproduksi secara alami di masa mendatang, dan c) mengutamakan pilihan pada makanan organik dalam konsumsi keluarga. Kuesioner yang digunakan mengacu pada alat ukur yang dikembangkan oleh Chan \& Lau (2000). Berdasarkan hasil uji coba kuesioner dengan 128 responden diperoleh reliabilitas dengan Cronbach Alpha sebesar 0,863 dengan nilai korelasi berkisar 0,6630,786 .

2. Variabel Sikap pada Makanan Organik (SB)

Sikap pada makanan organik yaitu perasaan atau evaluasi umum tentang membeli makanan organik berdasarkan keyakinan membeli makanan organik. Sikap pada makanan organik diukur dengan indikator a) yakin bahwa makanan organik bermanfaat bagi kesehatan, b) makanan organik aman dikonsumsi keluarga, c) makanan organik tidak tahan lama (cepat rusak) dan d) alami untuk dikonsumsi keluarga (Wijaya, 2013). Data variabel sikap terhadap makanan organik diperoleh dari hasil komputasi skor jawaban item kuesioner yang diisi oleh responden di pernyataan kuesioner penelitian. Berdasarkan hasil uji coba kuesioner dengan 128 responden diperoleh reliabilitas dengan Cronbach Alpha sebesar 0,937 dengan nilai korelasi butir berkisar 0,832-0,864.

3. Variabel Nilai Orientasi Alami Manusia (OAM) Nilai orientasi alami manusia didefinisikan sebagai tendensi hubungan manusia dengan lingkungan yang pada dasarnya akan mengarah pada kehidupan yang harmonis dalam kealamiannya 
(Chan \& Lau, 2000) yang diukur dengan alat ukur yang dikembangkan dari survey pendahuluan dan disesuaikan kuesioner yang dikembangkan oleh Chan \& Lau (2000). Nilai orientasi alami manusia diukur dengan indikator a) perlunya manusia memahami alam, b) perlakuan terhadap alam sepan-tasnya, c) menjaga keharmonisan dengan alam dan d) manusia bagian dari alam. Kuesioner yang digunakan mengacu pada alat ukur yang dikembangkan oleh Chan \& Lau (2000) yang disesuaikan dengan kondisi empiris di lapangan. Data skor variabel orientasi alami manusia diperoleh dari hasil komputasi skor jawaban butir alat ukur yang diisi oleh responden di pernyataan kuesioner penelitian. Berdasarkan hasil uji coba kuesioner dengan 128 responden diperoleh reliabilitas dengan Cronbach Alpha sebesar 0,886 dengan nilai korelasi butir berkisar 0,649-0,807.

4. Variabel Pengetahuan Organik (PO)

Pengetahuan organik didefinisikan sebagai kemampuan konsumen dalam mengidentifikasi sejumlah konsep yang berkaitan dengan produk organik melalui informasi yang dimiliki konsumen (Magistris \& Gracia, 2008; Chan \& Lau, 2000). Pengetahuan organik diukur dengan indikator a) self report pengetahuan makanan organik, b) memiliki informasi yang cukup tentang makanan organik, c) memahami tanda atau ciri makanan organik dan d) memahami pengertian organik. Alat ukur yang digunakan mengacu pada alat ukur yang dikembangkan oleh Magistris \& Gracia (2008). Data skor variabel pengetahuan organik diperoleh dari hasil komputasi skor jawaban butir dari alat ukur yang diisi oleh responden di kuesioner tentang pengetahuan organik. Berdasarkan hasil uji coba kuesioner dengan 128 responden diperoleh reliabilitas dengan Cronbach Alpha sebesar 0,955 dengan nilai korelasi butir berkisar 0,877-0,908.

Populasi penelitian yang digunakan sebagai sumber sampel adalah konsumen akhir makanan organik yaitu ibu rumah tangga. Teknik sampel menggunakan teknik non probabilitas dengan metode purposive sampling, dan dipilih adalah wanita yang telah menikah, yang mengetahui makanan organik dan melakukan pembelian untuk tujuan konsumsi keluarga, mengolah makanan atau memasak untuk konsumsi keluarga sehari-hari. Responden penelitian dalam penelitian ini meliputi tiga kota besar di pulau Jawa yaitu Jakarta, Yogyakarta dan Surabaya. Metode analisis data dalam penelitian ini menggunakan analisis model persamaan struktural atau disebut Structural Equation Modeling (SEM).

\section{HASIL PENELITIAN DAN PEMBAHASAN}

Sampel ditemui di sejumlah supermarket yang menyediakan makanan organik yang siap diolah seperti beras, sayur-sayuran dan buah-buahan. Secara berurutan responden yang berusia 26-30 tahun berjumlah 69 orang atau sebesar $13,4 \%$, responden yang berusia 36-40 tahun sebanyak 138 responden atau sebesar 26,7\% yang berusia 31-35 tahun berjumlah 93 orang atau sebesar $18,0 \%$, yang berusia $41-45$ tahun berjumlah 131 orang atau sebesar $25,4 \%$ dan yang berusia di atas 45 tahun berjumlah 85 orang atau sebesar $16,5 \%$.

Berdasarkan tingkat pendidikan responden, dapat diidentifikasi bahwa mayoritas responden memiliki pendidikan tinggi. Responden yang memiliki pendidikan SMU setingkat sebanyak 52 orang atau sebesar $10,1 \%$, responden yang memiliki pendidikan Diploma (D-1-D-3) sebanyak 57 orang atau sebesar $11,0 \%$, responden yang memiliki pendidikan S-1 sebanyak 241 orang atau sebesar $46,7 \%$, responden yang memiliki pendidikan S-2 sebanyak 163 orang atau sebesar $31,6 \%$ dan responden yang memiliki pendidikan S-3 sebanyak tiga orang atau sebesar $0,6 \%$

Berdasarkan data pekerjaan dapat diidentifikasi bahwa mayoritas responden memiliki pekerjaan wiraswasta yaitu sebanyak 211 responden atau sebesar $40,9 \%$, responden yang memiliki pekerjaan pegawai negeri sipil sebanyak 85 responden atau sebesar $16,5 \%$, responden yang memiliki pekerjaan pegawai swasta sebanyak 126 responden atau sebesar 24,4\% dan responden yang memiliki pekerjaan ibu rumah tangga sebanyak 94 responden atau sebesar 18,2\%.

Berdasarkan tingkat pendapatan keluarga, mayoritas responden tergolong menengah ke atas dengan pendapatan keluarga di atas Rp9.000.000,00 yaitu sebanyak 314 responden atau sebesar $60,9 \%$. Responden yang memiliki pendapatan Rp1.000.000,003.000.000,00 sebanyak empat responden atau sebesar $0,8 \%$, responden yang memiliki pendapatan $\mathrm{Rp}$ 3.000.100,00 - 5.000.000,00 sebanyak 13 responden atau sebesar $2,75 \%$. Responden yang memiliki pendapatan Rp 5.000.100,00-7.000.000,00 sebanyak 74 responden atau sebesar $14,3 \%$. Responden yang memiliki pendapatan $\operatorname{Rp~7.000.100,00~-~9.000.000,00~}$ sebanyak 111 responden atau sebesar $21,5 \%$.

\section{Uji Normalitas Data}

Normalitas data dapat diamati melalui skewness dan kurtosis value. Amatan dapat dilakukan dengan memperhatikan nilai $z$ atau $z$ value. Data dikatakan normal apabila memiliki nilai kritis di bawah nilai $z(z$ 
value). Nilai $z$ untuk probabilitas $1 \%$ sebesar $\pm 2,58$. Berdasarkan data uji normalitas diketahui bahwa semua data yang berasal dari data variabel manifes memiliki critical ratio atau nilai kritis di bawah $\pm 2,58$.

\section{Uji Validitas dan Reliabilitas}

Tabel 1 menunjukkan nilai muatan faktor yang diukur dari variabel laten melalui masing-masing variabel terobservasi. Nilai muatan faktor berkisar dari $0,75-0,93$ di atas 0,5 .

Tabel 1. Muatan Faktor (Factor Loading)

\begin{tabular}{lcccc}
\hline $\begin{array}{c}\text { Variabel } \\
\text { laten }\end{array}$ & $\begin{array}{c}\text { Nilai } \\
\text { orientasi } \\
\text { alami } \\
\text { manusia } \\
\text { (OAM) }\end{array}$ & $\begin{array}{c}\text { Pengeta- } \\
\text { huan } \\
\text { organik } \\
\text { (PO) }\end{array}$ & $\begin{array}{c}\text { Sikap } \\
\text { pada } \\
\text { makanan } \\
\text { organik } \\
\text { (SB) }\end{array}$ & $\begin{array}{c}\text { Intensi } \\
\text { beli (IB) }\end{array}$ \\
terobservasi & 0,85 & & & \\
\hline OAM1 & 0,83 & & & \\
OAM2 & 0,84 & & & \\
OAM3 & 0,75 & & & \\
OAM4 & & 0,90 & & \\
PO1 & & 0,93 & & \\
PO2 & & 0,92 & & \\
PO3 & & 0,92 & & \\
PO4 & & & 0,92 & \\
SB1 & & & 0,91 & \\
SB2 & & & 0,89 & \\
SB3 & & & 0,91 & \\
SB4 & & & & 0,85 \\
IB1 & & & & \\
IB2 & & & & \\
IB3 & & & & \\
\hline
\end{tabular}

Reliabilitas diperlukan untuk ukuran internal konsistensi indikator suatu konstruk. Pendekatan untuk menilai model pengukuran adalah mengukur reliabilitas komposit (composite reliability) dan ekstraksi varian (variance extracted). Mengacu pada formulasi di atas dapat diketahui nilai reliabilitas komposit dan ekstraksi varian masing-masing variabel seperti pada Tabel 2.

Berdasarkan Tabel 2 di atas dapat diketahui bahwa koefisien reliabilitas komposit untuk masingmasing variabel berkisar dari 0,72 (sikap pada makanan organik) hingga 0,95 (pengetahuan organik). Semua variabel berada di atas nilai penerimaan batas reliabilitas yaitu nilai minimum 0,7 . Nilai ekstraksi varian berada pada tingkat batas penerimaan yaitu nilai minimum 0,5 . Variasi nilai berkisar 0,54 (sikap pada makanan organik) hingga 0,84 (pengetahuan organik dan perilaku beli).

\section{Uji Kesesuaian Model Persamaan Struktural}

Hasil uji kesesuaian model menggunakan chisquare, CMIN/DF, GFI, AGFI, RMSEA, TLI, CFI dan ECVI diringkas seperti pada Tabel 3.
Tabel 2. Koefisien Reliabilitas Komposit dan Ekstraksi Varian

\begin{tabular}{|c|c|c|c|c|}
\hline Variabel & $\lambda_{i}$ & $\varepsilon_{i}$ & $\begin{array}{c}\text { Reliabilitas } \\
\text { komposit }\end{array}$ & $\begin{array}{c}\text { Ekstraksi } \\
\text { varian }\end{array}$ \\
\hline \multicolumn{3}{|c|}{ Nilai orientasi alami manusia } & 0,84 & 0,67 \\
\hline \multicolumn{3}{|l|}{ (OAM): } & & \\
\hline OAM1 & 0,85 & 0,72 & & \\
\hline OAM2 & 0,83 & 0,69 & & \\
\hline OAM3 & 0,84 & 0,71 & & \\
\hline OAM4 & 0,75 & 0,56 & & \\
\hline \multicolumn{3}{|c|}{ Pengetahuan organik (PO): } & 0,95 & 0,84 \\
\hline PO1 & 0,90 & 0,81 & & \\
\hline $\mathrm{PO} 2$ & 0,93 & 0,86 & & \\
\hline PO3 & 0,92 & 0,85 & & \\
\hline PO4 & 0,92 & 0,85 & & \\
\hline \multicolumn{3}{|c|}{$\begin{array}{l}\text { Sikap pada makanan organik } \\
\text { (SB): }\end{array}$} & 0,72 & 0,54 \\
\hline SB1 & 0,92 & 0,53 & & \\
\hline SB2 & 0,91 & 0,52 & & \\
\hline SB3 & 0,89 & 0,61 & & \\
\hline SB4 & 0,91 & 0,50 & & \\
\hline \multicolumn{2}{|l|}{ Intensi beli (IB): } & & 0,82 & 0,69 \\
\hline IB1 & 0,79 & 0,72 & & \\
\hline IB2 & 0,85 & 0,72 & & \\
\hline IB3 & 0,84 & 0,62 & & \\
\hline
\end{tabular}

Tabel 3. Hasil Goodness of Fit Model Pengukuran

\begin{tabular}{lccc}
\hline \multicolumn{1}{c}{ Indeks } & Cut off Value & Hasil & Evaluasi Model \\
\hline Chi square & Mendekati 0 & 80,738 & Baik \\
Probability & $\geq 0,05$ & 0,668 & Baik \\
CMIN/DF & $\leq 2,00$ & 0,928 & Baik \\
GFI & $\geq 0,90$ & 0,980 & Baik \\
AGFI & $\geq 0,90$ & 0,972 & Baik \\
RMSEA & $\leq 0,08$ & 0,000 & Baik \\
TLI & $\geq 0,90$ & 1,001 & Baik \\
CFI & $\geq 0,90$ & 1,000 & Baik \\
\hline
\end{tabular}

Tabel 3 menunjukkan bahwa model penelitian secara keseluruhan fit. Secara keseluruhan nilai $C h i$ square dengan probabilitas sebesar 0,668 >0,05 menunjukkan keseluruhan model fit (Overall goodness-of-fit). Selain itu setelah diuji kecocokannya nilai RMSEA, GFI, AGFI, TLI, dan CFI dibandingkan nilai acuan (cut off value) persamaan model struktural hasilnya baik.

\section{Uji Hipotesis}

Hasil uji kausalitas model dalam penelitian ini secara lengkap seperti pada Gambar 1.

Hasil bobot regresi antar variabel laten yang sering disebut sebagai estimasi loading factors atau lambda value dapat digunakan untuk menganalisis uji kausalitas variabel. Berdasarkan signifikansi nilai $C R$ (Critical Ratio) dengan nilai probabilitas $(p)=0.05$. Hasil bobot regresi uji kausalitas seperti pada Tabel 4. 


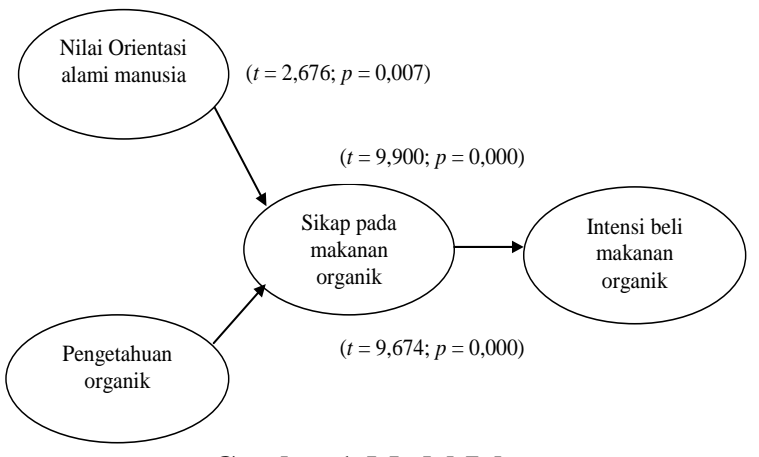

Gambar 1. Model Jalur

Tabel 4. Evaluasi Bobot Regresi Uji Kausalitas

\begin{tabular}{ccccc}
\hline Hipotesis & Variabel & Estimasi & $\boldsymbol{C R}$ & $\boldsymbol{P}$ \\
\hline Hipotesis 1 & $\mathrm{OAM} \rightarrow$ SB & 0,188 & 2,676 & 0,007 \\
Hipotesis 2 & $\mathrm{PO} \rightarrow$ SB & 0,410 & 9,674 & 0,000 \\
Hipotesis 3 & $\mathrm{SB} \rightarrow \mathrm{IB}$ & 0,335 & 9,900 & 0,000 \\
\hline
\end{tabular}

Keterangan:

$\mathrm{OAM}=$ Nilai orientasi alami manusia

PO = Pengetahuan organik

$\mathrm{SB}=$ Sikap pada makanan organik

$\mathrm{IB} \quad=$ Intensi beli

Penjelasan lebih lanjut analisis evaluasi bobot regresi tersebut dapat dijelaskan bahwa variabel nilai orientasi alami manusia mempengaruhi sikap pada makanan organik secara positif dan signifikan dengan tingkat signifikansi sebesar 0,007 lebih kecil dari nilai probabilitas $\leq 0,05$. Dengan demikian hipotesis 1 diterima. Variabel pengetahuan organik mempengaruhi sikap pada makanan organik secara positif dan signifikan dengan tingkat signifikansi sebesar 0,000 lebih kecil dari nilai probabilitas $\leq 0,05$. Dengan demikian hipotesis 2 diterima. Variabel sikap pada makanan organik mempengaruhi intensi beli makanan organik secara positif dan signifikan dengan tingkat signifikansi sebesar 0,000 lebih kecil dari nilai probabilitas $\leq 0,05$. Dengan demikian hipotesis 3 diterima.

Berdasarkan nilai koefisien terstandar dapat diketahui bahwa pengetahuan organik dominan mempengaruhi sikap pada makanan organik dibandingkan nilai orientasi alami manusia. Besarnya kontribusi variabel secara simultan terhadap variabel lainnya diringkas dalam Tabel 5.

Tabel 5. Koefisien Determinasi

\begin{tabular}{llc}
\hline \multicolumn{1}{c}{$\begin{array}{c}\text { Variabel yang } \\
\text { mempengaruhi }\end{array}$} & $\begin{array}{c}\text { Variabel yang } \\
\text { dipengaruhi }\end{array}$ & $\begin{array}{c}\text { Sumbangan } \\
\text { efektif }\end{array}$ \\
\hline $\begin{array}{l}\text { Sikap terhadap makanan } \\
\text { organik }\end{array}$ & $\begin{array}{l}\text { Intensi beli } \\
\text { makanan organik }\end{array}$ & $22,0 \%$ \\
$\begin{array}{l}\text { Kontrol perilaku } \\
\text { Norma subjektif }\end{array}$ & \\
$\begin{array}{l}\text { Orientasi alami manusia } \\
\text { Pengetahuan organik }\end{array}$ & $\begin{array}{l}\text { Sikap pada } \\
\text { makanan organik }\end{array}$ & $18,9 \%$ \\
\hline
\end{tabular}

Berdasarkan Tabel 5 di atas dapat diketahui bahwa variabel sikap pada makanan organik memiliki peran sebesar 18,9\% terhadap intensi beli makanan organik. Variabel nilai orientasi alami manusia dan pengetahuan organik memiliki peran sebesar 22,0\% dalam menjelaskan sikap pada makanan organik.

\section{Pembahasan}

\section{Hipotesis yang berkaitan dengan Nilai Orientasi Alami Manusia}

Hasil hipotesis mengenai pengaruh nilai orientasi alami manusia mendukung hipotesis 1 diterima. Hasil temuan menunjukkan nilai orientasi alami manusia berpengaruh positif dan signifikan terhadap sikap pada makanan organik. Hasil temuan penelitian ini konsisten dengan hasil temuan Dreezens et al. (2005); Krystallis et al. (2008); Grunert \& Juhl (1995); Loureiro et al. (2001); Magnusson et al. (2001); Durham \& Andrade (2005); Kuhar \& Juvancic (2005); Midmore et al. (2005); Padel \& Foster (2005); Verhoef (2005); Gracia \& de Magistris (2007); Stobbelaar et al. (2007); Chen \& Chai (2010) dan Wijaya \& Hidayat (2011). Hasil temuan menunjukkan semakin tinggi nilai orientasi alami manusia pada konsumen maka semakin baik sikap pada makanan organik, sebaliknya semakin rendah nilai orientasi alami manusia pada konsumen maka semakin buruk juga sikap pada makanan organik.

Makanan organik sebagai produk ramah lingkungan merupakan elemen sistem keyakinan individu (Dembkowski \& Lloyd, 1994). Secara spesifik, Arnould et al. (2004) dan Homer \& Kahle (1988) menjelaskan hubungan nilai dengan perilaku konsumen melalui mekanisme secara hierarkhi. Nilai berperan dalam membentuk sikap konsumen. Nilai merupakan pertimbangan yang fundamental bagi hubungan konsumen dengan lingkungan. Penduduk Asia memandang diri mereka sebagai bagian dari alam dan hidup harmonis dengan alam atau berorientasi pada alam (De Mooij, 2004) yang disebut Chan (2001) sebagai orientasi alami manusia (ManNature Orientation). Konsumen yang memiliki orientasi alami manusia cenderung mempertimbangkan akibat-akibat konsumsi pada lingkungan sehingga memiliki sikap ramah lingkungan (Chan, 2001) dan mendukung penggunaan produk organik (Wijaya \& Hidayat, 2011).

Filosofi nilai negara Timur berbeda dengan nilai di negara Barat. Sebagai contoh yang berkaitan dengan alam, nilai-nilai inti yang dianut oleh masyarakat Amerika adalah menaklukkan alam (Engel et al., 2005), berbeda dengan Asia yang cenderung mengutamakan kesimbangan alam (Chan, 2001). Ame- 
rika memiliki nilai menaklukkan alam, contohnya seperti menghadapi perubahan alam dan hama dengan bahan kimia, selain itu nilai menaklukkan alam juga ditunjukkan dengan iklan-iklan komersial yang ada (Engel et al., 2005).

Masyarakat Indonesia yang memiliki kecenderungan kolektivis memiliki makna hidup untuk harmoni atau seimbang dengan alam (Susana, 2009). Sebagai contoh pemetaan yang dilakukan oleh Susana (2009) berdasarkan konsep Koentjoroningrat menjelaskan bahwa masyarakat yang cenderung kolektivis yang ditunjukkan dengan pembangunan agraris, budaya tradisional, nilai-nilai gotong royong, hidup selaras dengan alam yang dicerminkan lewat acaraacara tradisi seperti slametan, tradisi di Gunung Merapi dan laut selatan, mengutamakan harmoni dibandingkan ambisi pribadi.

\section{Hipotesis yang berkaitan dengan Pengetahuan Organik}

Hasil penelitian menemukan adanya pengaruh pengetahuan organik secara positif dan signifikan terhadap sikap pada makanan organik. Hasil mendukung hipotesis 2 yang berkaitan dengan pengetahuan organik. Hasil temuan ini konsisten dengan temuan Amyx et al. (1994); Vining \& Ebreo (1990); Chan (1999); Yiridoe et al. (2005); Poelman et al. (2008); Schlegelmilch et al. (1996); Junaedi (2007); Gracia \& Magistris (2007); dan Magistris \& Gracia (2008). Hasil ini menunjukkan semakin tinggi tingkat pengetahuan organik dari konsumen maka semakin baik sikap pada makanan organik, sebaliknya semakin rendah tingkat pengetahuan organik dari konsumen maka semakin buruk sikap pada makanan organik.

Sikap merupakan susunan dari keyakinan dan evaluasi terhadap perilaku. Keyakinan dan evaluasi konsumen didasarkan pada berbagai pertimbangan melalui pengetahuan yang dimiliki konsumen. Konsumen yang memiliki pengetahuan organik cenderung memiliki sikap positif terhadap makanan organik karena yakin makanan organik bermanfaat bagi konsumen. Konsumen juga yakin dengan mengkonsumsi makanan organik, konsumen akan memperoleh manfaat seperti kesehatan, kealamian dan keamanan konsumsi yang dikandung dalam makanan organik. Magistris \& Gracia (2008) juga menjelaskan bahwa pengetahuan mewakili kemampuan konsumen dalam membedakan produk organik atau non organik serta membentuk sikap positif pada produk organik. Keyakinan terhadap peran hidup sehat merupakan determinan dalam penerimaan pangan (Verbeke, 2000).

Konsumen membeli produk-produk organik karena memiliki pengetahuan mengenai dampak kon- sumsi produk pada konsumen dan lingkungan (Chan, 2001). Child \& Poryzees (1998) menjelaskan bahwa kurangnya pengetahuan konsumen tentang kandungan dalam pangan fungsional akan menghambat proses keyakinan konsumen. Hal lain yang bersifat internal dalam membentuk sikap individu untuk berperilaku adalah ketersediaan informasi, keterampilan dan kemampuan yang memperkuat motivasi individu. Sikap cenderung berubah sesuai perubahan tingkat pengetahuan (Aertsens et al., 2009). Pengetahuan organik menyediakan informasi mengenai makanan organik dan manfaatnya sehingga memperkuat motivasi individu dalam mempertimbangkan pembelian makanan organik.

\section{Hipotesis yang berkaitan dengan Sikap pada Makanan Organik}

Hasil temuan membuktikan adanya pengaruh sikap pada makanan organik secara positif dan signifikan terhadap intensi beli makanan organik. Temuan tersebut mendukung hipotesis 3 yang diajukan dalam penelitian. Sikap pada makanan organik berpengaruh signifikan terhadap intensi beli makanan organik. Hasil temuan konsisten dengan hasil temuan Chan (1999); Chan \& Lau (2000); Dispoto (1997); LingYee (1997); Maloney \& Ward (1973); Wijaya \& Hidayat (2011); Gracia \& Magistris (2007); Kalafatis et al. (1999); Chiou, (1998); dan Aertsens et al. (2009). Hasil temuan menjelaskan bahwa semakin kuat sikap pada makanan organik maka semakin tinggi intensi beli, sebaliknya semakin lemah sikap pada makanan organik maka semakin rendah juga intensi beli konsumen.

Sesuai konsep dasar teori perilaku terencana menunjukkan bahwa sikap merupakan prediktor yang baik bagi intensi berperilaku. Teori perilaku terencana menyebutkan bahwa intensi adalah fungsi dari determinan sikap terhadap perilaku, yang merupakan dasar bagi pembentukan intensi. Menurut Ajzen (1991) terwujud tidaknya intensi sangat tergantung pada faktor eksternal dan internal. Faktor internal tergantung pada keyakinan dari individu dalam berperilaku dan dapat tidaknya berperilaku sedangkan faktor eksternal merupakan stimulus yang mendorong individu untuk berperilaku.

Semakin positif keyakinan individu akan akibat dari suatu obyek sikap, maka akan semakin positif pula sikap individu terhadap obyek sikap tersebut, demikian pula sebaliknya (Fishbein \& Ajzen, 1975). Evaluasi akan berakibat perilaku penilaian yang diberikan individu terhadap tiap-tiap akibat atau hasil yang diperoleh oleh individu. Apabila menampilkan atau tidak menampilkan perilaku tertentu, evaluasi 
atau penilaian ini dapat bersifat menguntungkan atau merugikan. Konsumen yang memiliki sikap yang positif terhadap makanan organik berdasarkan keyakinan dan evaluasi akan mengkonsumsi makanan organik karena dianggap bermanfaat bagi mereka sehingga menstimulasi niat konsumen membeli makanan organik.

\section{SIMPULAN DAN SARAN}

Berdasarkan analisis data dan pengujian hipotesis dapat disimpulkan sebagai berikut: Terdapat kesesuaian antara model perilaku beli makanan organik dengan data penelitian yang menggambarkan pengaruh orientasi alami manusia, pengetahuan organik, dan sikap terhadap makanan organik, terhadap intensi beli makanan organik. Hal ini didukung dengan persyaratan goodness of fit dari model. Dengan demikian model dalam penelitian ini dapat diaplikasikan dalam konteks konsumen pangan organik. Nilai orientasi alami manusia memiliki pengaruh positif dan signifikan terhadap sikap pada makanan organik.

Hal ini berarti semakin tinggi nilai orientasi alami manusia, maka semakin baik juga sikap pada makanan organik. Pengetahuan organik memiliki pengaruh positif dan signifikan terhadap sikap pada makanan organik. Hal ini berarti semakin tinggi pengetahuan organik, maka semakin baik juga sikap pada makanan organik. Sikap pada makanan organik memiliki pengaruh positif dan signifikan terhadap intensi beli makanan organik. Hal ini berarti semakin baik sikap pada makanan organik, maka semakin tinggi intensi beli makanan organik.

Penelitian ini memberikan kontribusi yang sifatnya teoritis dan praktis dalam wujud implikasi manajerial: Variabel nilai dan pengetahuan secara komprehensif merupakan prediktor yang baik bagi intensi beli konsumen melalui sikap. Nilai orientasi alami manusia dan pengetahuan organik berpengaruh terhadap sikap pada makanan organik secara parsial maupun simultan. Secara umum, model dasar teori perilaku terencana modifikasi dapat diaplikasikan dalam perilaku konsumen organik.

Secara praktis, berkaitan dengan pengaruh aspek pengetahuan terhadap sikap beli makanan organik, produsen organik khususnya yang bergerak di bidang makanan organik perlu memberikan informasi dalam proses edukasi konsumen seperti pemberian label organik dan informasi seperti manfaat makanan organik bagi kesehatan. Manfaat yang dapat diperoleh dari setiap jenis makanan organik. Komunikasi perlu dibangun oleh produsen dalam proses transfer informasi produk organik ke konsumen. Kim et al. (2001) berpendapat bahwa label pangan merupakan alat komunikasi yang digunakan untuk memenuhi kebutuhan informasi dan kesehatan. Secara umum, informasi yang diberikan meliputi merek, isi, kandungan bahan, mineral, vitamin, logo untuk klaim tertentu misalnya ramah lingkungan, klaim kesehatan, anjuran informasi dan penggunaan pola makan sehat (Hingginson et al., 2002).

Berdasarkan peran dari nilai orientasi alami manusia, diperlukan adanya penanaman nilai yang berorientasi alami manusia melalui sosialisasi kesadaran akan perilaku ramah lingkungan. Sosialisasi kesadaran akan ramah lingkungan dapat ditanamkan dari generasi ke generasi melalui jenjang formal seperti sekolah maupun non formal seperti keluarga. China contohnya, penanaman filosofi dilakukan oleh pemerintah melalui jenjang formal seperti lembaga pen-didikan atau sekolah maupun non-formal melalui keluarga yang dilakukan sejak usia dini hingga mengakar dalam kehidupan masyarakat. Peran pemerintah diperlukan dalam hal ini, sehingga akan tumbuh sikap positif dalam konsumsi produk organik yang berdampak pada pola konsumsi ramah lingkungan.

Edukasi yang berbasis ramah lingkungan perlu mendapat perhatian dari pemerintah. Melalui penanaman nilai orientasi alami manusia diharapkan mampu mencegah atau mengurangi degradasi lingkungan di Indonesia. Penanaman nilai juga akan menyadarkan manusia pentingnya hubungan manusia dengan alam sehingga tercipta pola konsumsi sehat berbasis ramah lingkungan.

Penelitian ini memiliki beberapa keterbatasan. Kategori produk yang digunakan dalam penelitian ini hanya pada produk pangan organik yang perlu diolah untuk konsumsi sedangkan masih banyak produk hijau lain yang diproduksi produsen seperti kosmetik, produk daur ulang, dan elektronik. Penelitian berikutnya dapat menggunakan produk hijau lainnya untuk memperkaya hasil penelitian serta sebagai perbandingan dengan hasil penelitian ini.

\section{DAFTAR REFERENSI}

Aertsens, J., Verbeke, W., \& Huylenbroeck, G. V. 2009. Personal Determinants of Organic Food Consumption: A Review. British Food Journal, 111(10): 1140-1167.

Ajzen, I. 1991. The Theory of Planned Behavior. Organizational Behavior and Human Decision Process, 50(2): 179-211.

Alba, J. W. \& Hutchinson, J. W. 1987. Dimension of Consumer Expertise. Journal of Consumer Research, 13(4): 411-454.

Amyx, D. A., Dejong, P. F., Lin, X. C. G., \& Weiner, J. L. 1994. Influencer of Purchase Intentions for 
Ecologically Safe Products: An Exploratory Study. The proceeding of the 1994 American Marketing Association's Winter Educators Conference. 5, AMA, Chicago,341-344.

Arbuthnot, J. \& Lingg, S. 1975. A Comparison of French and American Environmental Behaviours, Knowledge and Attitudes. International Journal of Psychology, 10(4): 275-281

Arnould, E. J., Price, L. L., \& Zinkhan, G. M. 2004. Consumers. New York: McGraw-Hill.

Baker, S., Thompson, K. E., Engelken, J., \& Huntley, K. 2004. Mapping the Values Driving Organic Food Choice: Germany vs the UK. European Journal of Marketing, 38(8): 995-1012.

Bhaskaran, S. \& Hardley, F. 2002. Buyer Belief, Attitudes and Behavior: Foods with Therapeutic Claim. Journal of Consumer Marketing, 19(7): 591-606.

Brucks, M. 1985. The Effect of Product Class Knowledge Information Search Behavior. Journal of Consumer Research, 12(1): 1-16.

Bui, M. H. 2005. Environmental Marketing: A Model of Consumer Behavior. Proceedings of the Annual Meeting of the Association of Collegiate Marketing Educators.

Chan, R. Y. K. 1999. Environmental Attitudes and Behavior of Consumers in China: Survey Findings and Implications. Journal of International Consumer Marketing, 11(4): 25-52.

2001. Determinants of Chinese Consumers Green Purchase Behavior. Psychology \& Marketing, 18(4): 389-413.

Chan, R. Y. K. \& Lau, L. B. Y. 2000. Antecedents of Green Purchases: A Survey in China. Journal of Consumer Marketing, 17(4): 338-357.

Chen, T. B. \& Chai, L. T. 2010. Attitude Towards the Environment and Green Product: Consumer Perspective. Management Science and Engineering, 4(2): 27-39.

Child, N. M. \& Poryzees, G. H. 1998. Food that Help Prevent Disease: Consumer Attitudes and Public Policy Implications. British Food Journal, 100(9): 419-426.

Chiou, J. S. 1998. The Effects of Attitude, Subjective Norm, and Perceived Behavioral Control on Consumers' Purchase Intentions: The Moderating Effects of Product Knowledge and Attention to Social Comparison Information. Proceedings of the National Science Council, 9: 298-308.

Chryssohoidis, G. M. \& Krystallis, A. 2005. Organic Consumer's Personal Value Research: Testing and Validating the List of Value Scale and Implementing a Value-based Segmentation Task. Food Quality and Preference, 16(7): 585599.
Churchill, G. A. 1979. A Paradigm for Developing Better Measures of Marketing Constructs. Journal of Marketing Research, 16(1): 67-73.

Dembkowski, D. S. \& Lloyd, S. H. 1994. The Environmental Value Attitude System Model. Journal of Marketing Management, 10(7): 593-603.

De Mooij, M. 2004. Consumer Behavior and Culture: Consequences for Global Marketing. California: Sage.

Dispoto, R. G. 1997. Interrelationships Among Measures of Environmental Acitivity, Emotionality and Knowledge. Educational and Psychological Measurement, 37(2): 451-459.

Divine, R. L. \& Lepisto, L. 2005. Analysis of Healthy Lifestyle Consumer. Journal of Consumer Marketing, 22(5): 275-283.

Dreezens, E., Martijn, C., Tenbult, P., Kok, G., \& De Vries, N. K. 2005. Food and Values: An Examination of Values Underlying Attitudes toward Genetically Modified and Organically Grown Food Products. Appetite, 44(1): 115-122.

Durham, C. A. \& Andrade, D. 2005. Health vs Environmental Motivation in Organic Preferences and Purchases. Paper presnted at the American Agricultural Economics Association Annual Meeting, Providence, 24-27 July.

Engel, J. F., Roger, D. B., \& Paul, W. M. 2005. Consumer Behavior. Forth Worth: Dreyden Press.

Fishbein, M. \& Ajzen, I. 1975. Belief, Attitude, Intention and Behavior: An Introduction to Theory and Research. California: Addison-Wes-ley Publishing Company Inc.

Follows, S. B. \& Jobber, D. 2000. Environmentally Responsible Purchase Behavior: A Test of a Consumer Model. European Journal of Marketing, 34(5): 723-746.

Fotopoulos, C. \& Krystallis, A. 2002. Purchasing Motives and Profile of the Greek Organic Consumer: A Countrywide Survey. British Food Journal, 104(9): 730-765.

Fraj, E. \& Martinez, E. 2006. Environmental Values and Lifestyles as Determining Factors of Ecological Consumer Behaviour: An Emprical Analysis. Journal of Consumer Marketing, 23(3): 113-144.

Geller, E. S. 1981. Evaluating Energy Conservation Programs: Is Verbal Report Enough? Journal of Consumer Research, 8(3): 331-335.

Gracia, A. \& Magistris, T. 2007. Organic Food Product Purchase Behaviour: A Pilot Study for Urban Consumers in the South of Italy. Spanish Journal of Agricultural Research, 5(4): 439451.

Grunert, S. C. \& Juhl, H. J. 1995. Value, Environmental Attitudes and Buying of Organic Foods. Journal of Economic Psychology, 16(1): 39-62. 
Hingginson, C. S., Rayner, M. J., Draper, S., \& Kirk, T. R. 2002. The Nutrition Label-which Information is Looked at? Nurition and Food Science, 32(3): 92-99.

Homer, P. M. \& Khale, L. R. 1988. A Structural Equation Test of the Value-attitude-behavior Hierarchy. Journal of Personality and Social Psychology, 54(4): 638-646.

Junaedi, S. 2007. The Roles of Consumer Knowledge and Emotion toward Ecological Issue: An Empirical Study of Green Study Consumer Behavior. International Journal of Business, 9(1): 81-99.

Kalafatis, S. P., Michael, Robert, E., \& Markos, H. T. 1999. Green Marketing and Ajzen's Theory of Planned Behavior: A Cross-market Examination. Journal of Consumer Marketing, 16(5): 441-460.

Kim, S. Y., Nayga, R. M., \& Capps, J. R. 2001. Food Label Use, Self Selectivity and Diet Quality. The Journal of Consumer Affair, 35(2): 246-363.

Kluckhohn, F. R. \& Strodtbeck, F. L. 1961. Variations in Value Orientations. Evanston Ill: Row Peterson.

Kotler, P. 2006. Marketing Management. New Jersey: Prentice Hall International, Inc.

Krystallis, A., Vassallo, M., Chryssohoidis, G., \& Perrea, T. 2008. Societal and Individualistic Drivers as Predictors of Organic Purchasing Revealed through a Portrait Value Questionnaire (PVQ) Based Inventory. Journal of Consumer Behaviour, 7(2): 164-187.

Kuhar, A. \& Juvancic, L. 2005. Modelling Consumer Preferences toward Organic and Integrated Fruits and Vegetables in Slovania. Paper presented at 97th EAAE Seminar on The Economics and Policy of Diet and Health, Reading. 21-22 April.

Laroche, M., Jasmin, B., \& Guido, B. F. 2001. Targeting Consumers Who are Willing to Pay More for Environmentally Friendly Products. Journal of Consumer Marketing, 18(6): 503520.

Ling-Yee, L. 1997, Effect of Collectivist Orientation and Ecological Attitude on Actual Environmental Commitment: The Moderating Role of Consumer Demographics and Product Involvement. Journal of International Consumer Marketing, 9(4): 31-53.

Lodorfos, G. N. \& Dennis, J. 2008. Consumers' Intent: In the Organic Food Market. Journal of Food Products Marketing, 14(2): 17-38.

Loureiro, M. J., McCluskey, J. J., \& Mittelhammer, R. C. 2001. Assesing Consumer Preferences for Organic, Eco-labeled and Regular Apples. Journal of Agricultural and Resource Economics, 26(2): 404-416.
Magistris, T. \& Gracia, A. 2008. The Decision to Buy Organic Food Products in Southern Italy. British Food Journal, 110(9): 929-947.

Magnusson, M. K., Arvola, A., Hursti, U. K., Aberg, L., \& Sjoden, P. 2001. Attitudes towards Organic Foods among Swedish Consumers. British Food Journal, 103(3): 209-226.

Maloney, M. P. \& Ward, M. P. 1973. Ecology: Lets Hear from the People: An Objective Scale for the Measurement of Ecological Attitudes and Knowledge. American Psychologist, 28(7): 583-586

Mansaray, A. \& Abijoye, J. O. 1998. Environmental Knowledge, Attitudes and Behavior in Dutch Secondary School. Journal of Environmental Education, 30(2): 4-11.

Martin, B. \& Simintras, A. C. 1995. The Impact of Green Product Lines on the Environment: Does what They Know Affect how They Fell? Marketing Intelligence \& Planning, 13(4): 16-23.

Midmore, P., Naspetti, S., Sherwood, A. M., Vairo, D., Wier, M., \& Zanoli, R. 2005. Consumer Attitudes to Quality and Safety of Organic and Low Input Foods: A Review. Aberystwyth: University of Wales.

Moreau, C. P., Lehman, D. R., \& Markman, A. B. 2001. Entrenched Knowledge Structure and Consumer Response to New Products. Journal of Marketing Research, 38(1): 14-29.

Mowen, J. C. \& Minor, M. 2006. Consumer Behavior: A Framework. New Jersey: Prentice-Hall.

Nayga, R. M. Jr. 2000. Nutrition Knowledge, Gender and Food Label Use. Journal of Consumer Affairs, 34(1): 97-112

Padel, S. \& Foster, C. 2005. Exploring the Gap between Attitudes and Behaviour: Understanding why Consumers Buy or Do Not Buy Organic Food. British Food Journal, 107(8): 606625.

Peattie, S. 1998. Promotional Competitions as a Marketing Tool in Food Retailing. British Food Journal, 100(6): 286-294.

Poelman, A., Mojet, J., Lyon, D., \& Sefa-Dedeh, S. 2008. The Influence of Information About Organic Production and Fair Trade on Preference for and Perception of Pineapple. Food Quality and Preference, 19(1): 114-121.

Ramsey, C. E. \& Rickson, R. E. 1976. Environmental Knowledge and Attitude. Journal of Environmental Education, 8(1): 10-18.

Said, M. A. 2003. Environmental Concerns, Knowledge and Practices Gap among Malaysian Teachers. International Journal of Sustainability in Higher Education, 4(4): 305-313.

Sampson, L. K. 2009. Consumer Analysis of Purchasing Behavior for Green Apparel. Thesis. North Carolina State University. 
Schahn, J. \& Holzher, E. 1990. Studies of Individual Environmental Concern: The Role of Knowledge, Gender and Backgrounds Variables. Environment and Behaviour, 22(6): 767-786.

Schlegelmilch, B. B., Bohlen, G. M., \& Diamantopoulos, A. 1996. The Link between Green Purchasing Decisions and Measures of Environmental Consciousness. European Journal of Marketing, 30(5): 35-55.

Schwartz, S. H. \& Bilsky, W. 1987. Towards Universal Psychological Structure of Human Values. Journal of Personality and Social Psychology, 53(3): 550-562.

Sihombing, S. O. 2007. Predicting Environmentally Purchase Behavior: A Test of the Value-attitudebehavior Hierarchy. The 2nd Indonesian Business Management Conference, Jakarta, 30 Januari.

Stobbelaar, D. J., Casimir, G., Borghuis, J., Marks, I., Meijer, L., \& Zebeda, S. 2007. Adolescents Attitudes toward Organic Food: A Survey of 15 to 16 year old school Children. International Journal of Consumer Studies, 31(4): 349-356.

Suprapto, B. \& Wijaya, T. 2012. Intention of Indonesian Consumers on Buying Organic Food. International Journal of Trade, Economics and Finance, 3(2): 114-119.

Susana, T. 2009. Pengaruh Orientasi Budaya Individual, Jenis Kelamin dan Orientasi Budaya Masyarakat terhadap Gejala Somatisasi dan Depresi Murni. Disertasi tidak diterbitkan. Yogyakarta: Universitas Gadjah Mada.

Tarkiainen, A. \& Sundqvist, S. 2005. Subjective Norms, Attitudes and Intentions of Finnish Consumers in Buying Organic Food. British Food Journal, 107(11): 808-822.

Tsakiridou, E., Boutsouki, C., Zotos, Y., \& Mattas, K. 2008. Attitudes and Behaviour towards Organic Products: An Exploratory Study. International Journal of Retail \& Distribution Management, 36(2): 158-175.
Verbeke, W. 2000. Influence on the Consumer Decision Making Process towards Fresh Meat: Insight from Belgium and Implications. British Food Journal, 102(7): 522-538.

Verhoef, P. C. 2005. Explaining Purchase of Organic Meat by Dutch Consumer. European Review of Agricultural Economics, 32(2): 245-267.

Verschuren, P. M. 2002. Functional Foods: Scientific and Global Perspectives. British Journal of Nutrition, 88(2): 125-130.

Vining, J. \& Ebreo, A. 1990. What Makes a Recycler? A Comparison of Recycler and Nonrecycler. Environmental Behavior, 22(1): 55-57.

Vlosky, R. P., Lucie, K. O., \& Renee J. F. 1999. A Conceptual Model of US Consumer Willingness-to-pay for Environmentally Certified Wood Products. Journal of Consumer Marketing, 16 (2): 122-136.

Westrate, J. A., Poppel, G. V., \& Verschuren, P. M. 2002. Functional Foods, Trends and Future. British Journal of Nutrition, 88(2): 233-235.

Wijaya, T. 2013. Sikap terhadap Makanan Organik, Norma Subjektif, Kontrol Perilaku Konsumen Makanan Organik: Konsep dan Pengukuran. Jurnal Ilmu Sosial dan Ekonomi, 3(1): 20-33.

Wijaya, T. \& Hidayat, A. 2011. Model Intensi Pembelian Makanan Organik. Call for Paper Update Ekonomi, Akuntansi dan Bisnis Indonesia, Fakultas Ekonomi UII-Yogyakarta, 28 Juni.

Wood, S. L. \& Lynch, J. G. Jr. 2002. Prior Knowledge and Complacency in New Product Learning. Journal of Consumer Research, 29(3): 416-426.

Yiridoe, E. K., Bonti-Ankomah, S., \& Martin, R. C. 2005. Comparison of Consumers Perception towards Organic versus Conventionally Produced Foods: A Review and Update of the Literature. Renewable Agriculture and Food System, 20(4): 193-205.

YLKI. 2012. Survei Konsumen Organik Indonesia, (http://www.organicindonesia.org/05infodatanews. php?id=443, diakses 1 Maret 2013). 